\title{
Foreword: \\ Curating on the \\ Cutting Edge
}

\author{
Lucy R. Lippard
}

Curating at the Edge is an intriguing hybrid, combining a manual on how to create a distinctive university art center with an informed critical text on art reaching across the U.S. / Mexican border-and by extension over all borders. This is a book about process and collaboration on many fronts-between curator and artists, artists and artists, university and curators, and cities and nations. "Border as center" is how Kate Bonansinga describes the institutional identity of the Stanlee and Gerald Rubin Center for the Visual Arts at the University of Texas at El Paso. Her searches for art that illuminates and expands that identity, the resulting artists' proposals, and the intricate process of executing the installations are the core of her book. These artworks, each with its own set of problems and triumphs, reflect the shifting social dynamics of the border as it permeates further and further north and south, becoming a local/global nexus with reverberations across many other borders.

El Paso and Juárez are unique in their proximity within the "most populated urban cluster on any border in the world." Sharing a population of around I.4 million, they are separated only by the Rio Grande. Until around 2009, they were intimate sister cities. Then Juárez, thanks to rampaging drug cartels, official corruption, and ineffective governmental policies, was labeled the world's most dangerous city, while El Paso remains one of the safest cities of its size in the world. Given this tragic contrast, the Rubin Center's ongoing collaboration with the Universidad Autónoma de Ciudad Juárez (UACJ)—even 
when that beleaguered city was out-of-bounds to those UTEP students living in El Paso - surely meant a great deal to everyone on both sides of the river. In 2009, Tijuana-based Tania Candiani illuminated this relationship with Battleground, a performance on the hillside next to the art center. Students with helmets and weapons made from domestic objects (a sad reversal of "swords into ploughshares") chose to be either Warriors or Defenders, protecting Juárez from Juárez. Originally planned to play across the border, it was live-streamed to Juárez and projected in the Rubin galleries.

The connection between curating and place, on the model of California's groundbreaking Border Arts Workshop and insite, is one of the lessons this book has to offer. Nearly 80 percent of the UTEP student body is Mexican American; most belong to the first generation in their families to attend college. One thing that stands out about the artists and curators discussed here is their respect for these students. The art shown at the Rubin is as complex and challenging as anything exhibited in far better-funded and more prestigious institutions. Although the Rubin also presents smaller and more conventional art exhibitions, the choice of commissioned installations as the focus was a daring one. Even hanging neatly framed and delivered works can be a touchy business; installation art is far more complicated. For the artist it offers a way to try something new, complex, temporary, and sometimes place-specific. For the hosting institution it offers all kinds of out-of-the-box learning possibilities. For audiences and faculties unaccustomed to contemporary art, it offers new and brain-stretching experiences. For the students, it means regular participation in the construction of the innovative artworks, according to the Rubin's mission: to become a laboratory for experimentation where "visiting artists would be the researchers and UTEP students would be their assistants."

For the curator, it provides innumerable headaches. Bonansinga candidly discusses the evolution of an impressive number of very disparate works- the aesthetic, financial, academic, and marketing decisions made over the decade in which she forged first the Rubin Center itself (when it opened in 2004 she was its only full-time employee) and then its remarkable exhibition program. She makes the challenges sound easy, admitting mistakes and disappointments, but the attentive reader can see between the lines. There are inevitably minor clashes as the curator tries to keep peace between project and budget, possibility and impossibility, while pursuing a shared vision of the completed work. Accounts of last minute mind-changing are common, throwing the best-laid plans into disarray. On the unpredictably organic growth of the SIMPARCH collective, Bonansinga remarks wryly: "More people, more talent, and more chaos." 
Above all, Bonansinga trusts artists - the mark of a good curator. She is open, flexible, and follows her hunches. Amazingly, there are no disasters. Most of the artists selected for commissions were already nationally or internationally known. Only one, Adrian Esparza, was born and raised in El Paso (and resides there still), and one other (Margarita Cabrera, not shown at the Rubin, but accorded prime space in the book) is currently El Paso-based. The few Anglos are or have been residents of border states. Perhaps most surprising, given the potentially controversial subjects and images routinely selected for the Rubin, is that the UTEP administration trusted Bonansinga, supporting her stated intention to create "spectacular exhibitions [by living artists], with minimal resources." Partnerships like that between the curator and UTEP president Diana Natalicio are rare.

The Rubin's program is remarkable in its consistent challenges to the status quo and its consistent ventures into social and political issues illuminated by "cutting edge" contemporary art. The titles of works presented at the Rubin and elsewhere by Alejandro Almanza Pereda reflect the risk-taking flavor of the program itself: Just Give Me a Place to Stand, The Heaviest Baggage for the Traveler is the Empty One, The Fan and the Shit, Andiamo, Stand Clear. Pereda's works are sometimes weighty and sometimes precarious, with floating furniture and fluorescent pillars, reflecting the tensions of a life lived across borders. Construction and destruction are recurring themes. In Lines of Division, Mexico City-based Enrique Ježik, after abandoning a plan to exhibit the rubble of a demolished Mexican maquiladora, turned to political mapping in a raw, even brutal, installation including plywood panels outlining contested borders around the world. He executed the final piece with a chainsaw at the opening.

"By building, we are destroying," observes Tijuana-based ERre (Marcos Ramírez), whose hard-hitting and visually powerful work includes a twoheaded Trojan horse on the border, a slum shanty transported to official central Tijuana, and a billboard aimed at U.S. border vigilantes. He focuses on walls as icons of social injustice, dubious development, and cultural misunderstandings. His four-part installation at the Rubin was ironically titled To Whom It May Concern: War Notes. Among his targets are U.S. bombings in Afghanistan. When a similarly aimed work was censored in Pennsylvania, he demanded, "Are people outraged because a Mexican artist has bothered to highlight this history? Or do I perceive an underlying shame?"

The subjects of violence and betrayal are unavoidable in this context. The artists commissioned by the Rubin deal directly and indirectly with violence against women, Narquitecto tunnels under the wall, desperate attempts to live 
in a skewed economy, and the layers of social injustice found on both sides of the wall. Women's labor, women's bodies, and protection of the family and the domestic sphere in the midst of crisis are Tania Candiani's themes. And Liz Cohen (daughter of Colombian immigrants) defies gender roles and the male gaze by offering a flirtatious persona in bikini and high heels while she works in an auto body shop and builds her own hybrid car - the Trabantimino, a cross between the German Trabant and Chevy El Camino. New Mexican (now New Yorker) Nicola Lopez, in the Claiming Space exhibition, showed abstract installations of woodcut-printed and metal-entwined Mylar, evoking the twists and turns of thoughtless urban planning and roads that "don't get you anywhere ..." "One lives within the local depending upon how one participates in globalization," says anthropologist Néstor García Canclini, with regard to the work of Julio César Morales, whose Informal Economy Vendor \#2 shattered an image of a Mexican street vendor into pieces across the wall.

Bonansinga and her many collaborators for the most part reject "identity politics" in favor of showing "how identity is shifting in a globalized world." The "established stereotypes of Latino art"-what has been called the "ethnographic look-virgins and bloody hearts, etc." - are notably absent, although it must be said that these images remain significant to many artists in the border states and their possibilities have not yet been exhausted. Similar themes are incorporated into the Rubin installations by artists skilled in doing what the art world does best-having it both ways: the formal use of meaningful local materials leading to both personal and political interpretations. Adrian Esparza's Unknitting pieces, for instance, stem from his childhood familiarity with crafts, too often considered "low art." As a "high artist," he simultaneously challenges and celebrates tradition by transforming/deconstructing/ unraveling striped serapes into geometric artworks with social implications. Margarita Cabrera's community-based work, which evolved from soft sculptures of machine parts from the maquiladoras (referring to the Juárez "femicides") and a fabric Vocho from the Puebla Volkswagen plant, is now often presented as the product of a folk art cottage industry called Florezca. Her fired clay replica of a tractor covered with flowers, birds, and butterflies (Arbol de la Vida) raises issues of aesthetic authorship and international trade relations, while at the same time empowering individual artisans and immigrants.

In 20 ro the Rubin faced what Bonansinga called "a moral dilemma"-an invitation to take part in a series of events marking the bicentennial of Mexico's independence from Spain and the centennial of the Mexican Revolution at a time when El Paso's sister city was bleeding to death and people were visibly powerless. ("How many revolutions are required to effect change?" asks ERRE.) 
Even arriving at a title for the show proved difficult. Kerry Doyle, a colleague at the Rubin, co-curated Contra Flujo: Independence and Revolution with Mexican Karla Jasso, and it was indeed "Against the Flow" of nationalist chauvinism. I-Machinarius by Marcela Armas was a huge wall piece with rotating cogs that kept in motion an oiled chain forming the outline of Mexico, upside down. A veil of crude oil flowed over it, providing an unveiled criticism of Mexico's human, financial, and natural resources "drained by and into the United States" in a relentless cycle. In the less confrontational but equally significant Cross Coordinates, Ivan Abreu, who concentrates on creating "context rather than content" and emphasizes collective over individual experience, invited motley pairs of people to balance a four-foot carpenter's level. The piece was publicly performed in a number of ironic and hopeful circumstances across social and national barriers.

The writer Teddy Cruz contends that "the most dramatic conflict on the border is between the natural and the political." The Rubin has featured several pieces dealing with this subject, among them the Tom Leader Studio's Snagged. Initially proposed as a huge structure filled with detritus from the border (evoking the ubiquitous western landscapes of plastic bags caught on barbed wire fences), it then shifted to become a piece about irrigation ditches, drought, erosion control, and Southwest agriculture, described by Bonansinga as a "ghost-like imprint of a section of El Paso's irrigation system . . . death waiting for life." Participating architect Alan Smart described the piece (made of steel and organic cotton) as a comment on the border as a permeable and impermeable membrane, with water as "a metaphor for economic or population flows ...."

SIMPARCH (Matt Lynch and Steve Badgett) has specialized in funky architectural pieces, augmented by music, sound, and humor, that promote sustainability and often debunk American myths. At the Rubin, after some abrupt changes of direction, they built Hydromancy, a version of their "Dirty Water Initiative." A black plastic tank (ubiquitous in Mexico) was erected on the hillside next to the Rubin holding dirty water from the Rio Grande. The water was then purified in three solar stills and piped into the galleries, becoming a "community well or fountain," at which the audience was invited to drink. (The stills were later recycled, given to a nonprofit in Juárez.)

Although the darker side of border relations unavoidably dominates artists' responses at this moment in history, works like these offer a hopeful determination to change. Lights at the end of the tunnel might also bring an end to borders, as suggested by Jay Atherton's and Cy Keener's Light Lines, emphasizing "the borderlessness of air and light," through mirrors, shadows, 
and the masking of the Rubin's clerestory windows in an act of "understated activism." Similarly, Leo Villareal's Solar Matrix - a random field of lights on the nearby hillside, fueled by solar energy and recalling the notorious Marfa Lights - transmitted a mysterious beauty across the landscape.

I have visited the Rubin only once, to see a stairwell installation by my former neighbor, El Paso native Isabella Gonzales. I was impressed. I know of few other institutions that can even approach the quality and commitment of the Rubin, a situation that I hope will continue under its next leader. (Bonansinga left UTEP in July 20I2.) This brief foreword can only hint at the breadth and depth of the program over the last decade. But the book does it justice. Read on ... 
CURATING

$$
\begin{array}{r}
A T \\
\text { THE } \\
\text { EDGE }
\end{array}
$$


THIS PAGE INTENTIONALLY LEFT BLANK 